\title{
THE INFLUENCE OF FDI ON DOMESTIC INNOVATION: AN INVESTIGATION USING STRUCTURAL BREAKS
}

\author{
Mingbo Zheng ${ }^{a}$, Gen-Fu Feng ${ }^{a}$, Jun Wen ${ }^{a}$, Chun-Ping Chang ${ }^{b}$
}

\begin{abstract}
This paper investigates the influence of foreign direct investment on innovation by employing the panel cointegration method incorporating multiple structural breaks and a dynamic common correlated estimation for 34 countries over the period 1991-2016. Our findings indicate that the series of innovation and foreign direct investment are stationary after considering the potential structural breaks and that the external shock is mainly from country-specific shocks. Our results also suggest that a long-run co-integrated relationship exists with one break between foreign direct investment and innovation. Furthermore, the estimation based on the dynamic common correlated estimation shows that foreign direct investment has a long-run significant positive influence on technological innovation. Our findings shed light on the importance of accounting for structural breaks when discussing the relationship between foreign direct investment and technological innovation.
\end{abstract}

Keywords: Innovation, patent, trademark, FDI, structural breaks, cointegration JEL Classification: C33, O34, F23

\section{Introduction}

With the expectation that foreign firms exhibit technology spillover and labour pooling, most countries implement generous preferential policies and relaxed business environments to attract foreign direct investment (FDI) (Javorcik and Spatareanu, 2011). However, the empirical literature for the spillover effect of FDI has produced ambiguous results. For example, Cheung and Lin (2004) find that FDI can improve innovation activities through the channels of reverse engineering, skilled labour turnover, demonstration effects, and supplier-customer relationships (Haskel et al., 2007). By contrast, Aitken and Harrison (1999) note that FDI has a negative impact on the productivity of wholly domestically

\footnotetext{
a School of Economics and Finance, Xi' an Jiaotong University, Shaanxi, China

b Shih Chien University in Kaohsiung, Kaohsiung, Taiwan

Email: cpchang@g2.usc.edu.tw
} 
owned firms (Lu et al., 2017). Innovation also entails more FDI from multinational firms, which explore capabilities available in the host country to pursue sustainable competitiveness (Chen and Yeh, 2012). These findings concentrate on one direction only, from FDI to innovation, but an issue hence arises: Do FDI and innovation move together? More particularly, since the structural break is a common phenomenon in economic series (Chang and Lee, 2015), do we need to take multiple breaks into consideration?

By employing the panel cointegration test with structural breaks, the goal of this paper is to examine the long-run relationship between innovation and FDI based on panel data over the period 1991-2016 in 34 countries. More specifically, we not only account for multiple breaks in the panel unit root test, but also utilize the panel cointegration test with structural breaks proposed by Westerlund and Egerton (2008) and Banerjee and Carrion-i-Silvestre (2015). Next, we use the growth rate of patents and trademarks (Patent and Trademark) and the growth rate of FDI (FDI) as measurements for innovation and FDI, respectively. In addition, to investigate the influence of FDI on innovation, we employ the panel dynamic common correlated estimation (DCCE) model. We believe that our research provides additional evidence of the relationship between innovation and FDI, as well as evidence from incorporating multiple breaks in the panel cointegration test.

The effect of FDI on technological innovation in recent years has drawn widespread scholarly attention. Many studies in the literature claim that FDI is associated with increased innovation performance (Liang et al., 2017). Vahter (2011) finds that the presence of FDI contributes to subsequent process and product innovation for these incumbents, indicating the existence of a technology transfer channel (Li et al., 2017). However, many studies hold that the technology spillover of FDI is conditional to various factors (Joen et al., 2013; Girma et al., 2015). As Madsen et al. (2010) state, technology spillover cannot appear automatically as mastering technology needs enough time, resources, investment in knowledge, and training for technicians and engineers. Malik (2015) shows that technology spillovers from FDI are constrained by absorptive capacity and ownership structure. Some empirical results show a negative effect of FDI on innovation. Stiebale and Reize (2011) find that foreign acquisitions exert a negative influence on average R\&D expenditures and innovation activities.

The existing literature also notes that knowledge seeking is a critical factor affecting the location choice of FDI (Kim and Aguilera, 2016). International enterprises do not look solely for new market and natural resources, but also seek access to advanced technology and knowledge assets (Dunning, 2000; Ramasamy et al., 2012). Santangelo and Meyer (2011) present that firms tend to acquire innovative capability and technological know-how overseas. Cui et al. (2014) note that advanced technology is a crucial target that firms seek 
to obtain through FDI. Nielsen et al. (2017) also point out that a firm's technological knowledge is generally a positive driver for its internationalization.

More importantly, the literature demonstrates that it is necessary to consider the structural break in the cointegration test. As Westerlund (2006) offers, structural breaks are usually observed in macroeconomic series, such as real output and trade. Thus, ignoring them in an estimated model will lead to biased results. From the literature, we find that the FDI series exhibit structural breaks in the unit root test (Sbia et al., 2014; Solarina and Shahbaz, 2015) and the cointegration test (Seker et al., 2015). Hence, to investigate the long-run influence of FDI on innovation, we do not simply consider structural breaks in the unit root test and cointegration test, but also incorporate the estimated break point in the regression model, providing more detailed and powerful results.

Our results indicate that FDI, Patent, and Trademark follow a stationary trend under the panel Lagrange Multiplier (LM) unit root test with structural breaks. The PANICCA test further shows that the non-stationarity of structural shifts mainly comes from countryspecific factors. The results of the panel cointegration test reveal a long-run cointegration relationship between FDI and Patent as well as between FDI and Trademark when structural breaks are considered. The DCCE estimation hence indicates that FDI has a positive influence on innovation.

The rest of this paper runs as follows. Section 2 presents a brief introduction about the panel unit root test with structural breaks, the panel cointegration test with multiple structural breaks, and the dynamic common correlated estimator. Section 3 provides the data source and variables and discusses the empirical results. Section 4 concludes.

\section{Methodology}

\subsection{Panel unit root tests with structural breaks}

In this section we follow the panel LM unit root test with level structural breaks developed by Im et al. (2005) to check for panel stationarity of the variables. The panel LM unit root test of Im et al. (2005) can account for potential unknown structural breaks among series and test the unit root in every cross-section. Hence, the data-generating process is:

$$
y_{i t}=\gamma_{1 i}+\gamma_{2 i} t+\delta_{i} T B_{i t}+x_{i t}
$$

where $y_{i t}$ denotes $F D I$ or both innovation variables in the country $i$ at the time $t ; t=1, \ldots, T$ represents time periods; $i=1, \ldots, N$ represents the number of cross-sections; $x_{i t}=\phi_{i} x_{i t-1}+\varepsilon_{i t}$; $T B_{i t}=1$ for $t>B P_{i}$ and 0 otherwise; $B P_{i}$ represents the break point in the country $i$; and $\varepsilon_{i t}$ is the zero-mean error term. 
The idea of Im et al. (2005) to construct the panel LM unit root test statistics is averaging the univariate LM test statistics for each country. Thus, before computing the panel LM test statistics, we have to get the univariate LM unit root statistics in each country. Amsler and Lee (1995) show that the LM statistics for the country $i$ are obtained as a $t$-statistic from testing $\varphi=0$ in the regression:

$$
\Delta y_{i t}=\gamma_{2 i}+\delta_{i} T B_{i t}+\varphi S_{i, t-1}+\mu_{i t}
$$

where $S_{i t-1}$ is the de-trended lagged dependent variable $y_{i t-1}$; and $\mu_{i t}$ is the stochastic term. Let $L M_{i}$ represent the univariate LM unit root statistics for the country $i$; hence, the panel unit root statistics are given by $L M_{N T}=(1 / N) \sum_{i=1}^{N} L M_{i}$. The standardized panel LM unit root test statistics are:

$$
\Gamma_{L M}=\frac{\sqrt{N}\left(L M_{i}-E\left(\tau_{L M}\right)\right)}{\sqrt{V\left(\tau_{L M}\right)}} .
$$

Here, $E\left(\tau_{L M}\right)$ and $V\left(\tau_{L M}\right)$ correspondingly denote the expected value and variance of $\tau_{L M}$ for the case where there are no structural shifts in the series. Im et al. (2005) show that the presence of structural shifts does not affect the asymptotic distribution of these panel LM statistics as they follow the standard normal distribution.

The PANICCA test (combing principal components-based panel analysis of non-stationarity in idiosyncratic and common components, "PANIC" and cross-section average, "CA") developed by Reese and Westerlund (2016) is also utilized to analyse the structural break shifts whether from the common factors or from idiosyncratic components. The PANICCA test of Reese and Westerlund (2016) has the advantage of distinguishing the underlying sources of non-stationarity. The data-generating process is as follows:

$$
y_{i t}=\phi_{i}^{\prime} D_{t, p}+\eta_{i}^{\prime} G_{t}+e_{i t}
$$

where $D_{t, p}$ refers to a polynomial trend function given as $D_{t, p}=\left(1, \ldots, t^{p}\right)^{\prime}$ with $(p+1) * 1$ trend; $G_{t}$ implies an $r * 1$ vector of common factors; $\eta_{i}$ is the corresponding factor loading; $e_{i t}$ is the unit-specific idiosyncratic error term; and $D_{t, p}$ has two options: $p=0$ for the intercept only and $p=1$ for both intercept and trend. Whether the estimated $\tilde{G}_{t}$ and $\tilde{e}_{i t}$ : are stationary is tested through $\tilde{G}_{t}=\rho \tilde{G}_{t-1}+u_{t}$ and $\tilde{e}_{i t}=\gamma \tilde{e}_{i t-1}+v_{i t}$. For the stationarity of $\tilde{e}_{i t}$, Reese and Westerlund (2016) propose three statistics represented by Pap, Pbp, and PMSBp for the two cases of $p=0$ and $p=1$. For the stationarity of $\tilde{G}_{t}$, the augmented Dickey-Fuller (ADF) statistics are carried out following the suggestion in Bai and $\mathrm{Ng}$ (2004). 


\subsection{Panel cointegration tests with structural breaks}

Westerlund and Edgerton (2008) develop a simple test with two statistics in order to examine the null hypothesis of no cointegration in panel data. Compared with the conventional panel cointegration test, the main advantage of the Westerlund and Edgerton (2008) cointegration test is that it considers cross-section dependence and unknown heterogeneous shifts in both the constant and the slope of the cointegrated regression. Consider the following model:

$$
\begin{aligned}
& y_{i t}=\theta_{i}+\omega_{i} B_{i t}+x_{i t}^{\prime} \beta_{i}+\left(B_{i t} x_{i t}\right)^{\prime} \gamma_{i}+z_{i t} \\
& x_{i t}=x_{i t-1}+\mu_{i t}
\end{aligned}
$$

The $k$-dimensional vector $x_{i t}$ represents the regressors and is defined as a random walk. Here, $D_{i t}$ denotes the break point such that $D_{i t}=1$ for $t>T_{i}$ and 0 otherwise; $\theta_{i}$ and $\beta_{i}$ refer to the intercept and slope before the shift, while $\omega_{i}$ and $\gamma_{i}$ refer to the change in the intercept and slope after the shift; and $z_{i t}$ is the zero-mean error term, which is independent across units. We now present the disturbance term $\mu_{i t}$, which takes cross-sectional dependence into account by including the unobserved common factors:

$$
\begin{aligned}
& \mu_{i t}=\lambda_{i} G_{t}+v_{i t} \\
& F_{j t}=\rho_{j} F_{j t-1}+u_{j t} \\
& \phi_{i}(L) \Delta v_{i t}=\phi_{i} v_{i t-1}+e_{i t}
\end{aligned}
$$

We note that $\phi_{i}(L)=1-\sum_{i=1}^{p_{i}} \phi_{i j} L^{j}$ indicates a scalar polynomial in the lag operator $L$; $G_{t}$ shows the vector of unobservable common factors; $\lambda_{i}$ means the vector of corresponding factor loading; $v_{i t}$ is independent of $e_{i t}$ and $\mu_{i t}$ for all $i$ and $t$; and $e_{i t}$ is an error term with zero mean. The null hypothesis in Westerlund and Edgerton (2008) is that all individuals are cointegrated, while the alternative one is that the first $M$ individuals are cointegrated while the others are not. Thus, the panel cointegration test statistics proposed by Westerlund and Edgerton (2008) are given as:

$$
\begin{aligned}
& Z_{\phi}(N)=\sqrt{N}\left(\overline{L M}_{\phi}-E\left(B_{\phi}\right)\right) \\
& Z_{\tau}(N)=\sqrt{N}\left(\overline{L M}_{\tau}-E\left(B_{\tau}\right)\right),
\end{aligned}
$$

where $\overline{L M}_{\phi}=(1 / N) \sum_{i}^{N} L M_{\phi}(i), \quad \overline{L M}_{\tau}=(1 / N) \sum_{i}^{N} L M_{\tau}(i), \quad L M_{\phi}(i)=T \hat{\phi}_{i}\left(\hat{\varpi}_{i} / \hat{\sigma}_{i}\right)$, $L M_{\tau}(i)=\hat{\phi}_{i} / S E\left(\hat{\phi}_{i}\right)$, and $\hat{\phi}_{i}$ is the estimated $\phi_{i}$ in Equation 9 of Westerlund and Edgerton (2008). 
Banerjee and Carrion-i-Silvestre (2015) design a procedure to test a cointegrated relationship. The Banerjee and Carrion-i-Silvestre (2015) panel cointegration test allows for structural breaks in both the deterministic components and the cointegrating vector and also takes cross-section dependence among units into account. The data-generating process with structural form is given as:

$$
\begin{aligned}
& y_{i t}=D_{i t}+x_{i t}^{\prime} \delta_{i t}+u_{i t} \\
& u_{i t}=F_{t}^{\prime} \pi_{i}+e_{i t} \\
& (I-L) F_{t}=C(L) w_{t} \\
& \left(1-\rho_{i} L\right) e_{i t}=H_{i}(L) \varepsilon_{i t} \\
& x_{i t}=\kappa_{i}+x_{i t-1}+G_{t}^{\prime} \varsigma_{i}+\Xi(L) v_{i t} \\
& G_{t}=\Gamma(L) \varpi_{i},
\end{aligned}
$$

where $t=1, \ldots, T$ represent time period; $i=1, \ldots, N$ represent units; $y_{i t}$ and $x_{i t}$ are respectively the scalar and the vector of a stochastic process whose elements follow I(1); C(L) $C(L)=\sum_{j=0}^{\infty} C_{j} L^{j} ; \quad H_{i}(L)=\sum_{j=0}^{\infty} h_{i j} L^{j} ; \quad \Xi_{i}(L)=\sum_{j=0}^{\infty} \Xi_{i j} L^{j} ;$ and $\Gamma(L)=\sum_{j=0}^{\infty} \Gamma_{j} L^{j}$. Here, the deterministic term $D_{i t}$ is formulated by:

$$
D_{i t}=\mu_{i}+\beta_{i} t+\sum_{j=1}^{m_{i}} \theta_{i j} D U_{i j t}+\sum_{j=1}^{m_{i}} \gamma_{i j} D T_{i j t},
$$

where $D U_{i j t}=1$ and $D T_{i j t}=t-T_{i j}$ for $\mathrm{t}>T_{i j}$ and 0 otherwise; and $T_{i j}$ implies the time period of the $j^{\text {th }}$ breaks, $j=1, . ., m_{i}$ for individual $i$. The cointegrating vector is a function of time, and hence:

$$
\delta_{i t}=\delta_{i j} \text { for } T_{i j-1}^{c}<T_{i j}^{c}
$$

We note that $T_{i 0}^{c}=0, T_{i, n_{i}+1}^{c}=T$, and $T_{i j}^{c}$ represent the time of the $j^{\text {th }}$ break, $j=1, \ldots, n_{i}$ for the unit $i$. In this study we use Model 5 in Banerjee and Carrion-i-Silvestre (2015) as it accounts for the presence of multiple structural break effects on both the level and the cointegrating vector of the model and allows unobservable structural breaks. The null hypothesis is that there is no panel cointegration in all units. In the process of constructing the panel statistics, Banerjee and Carrion-i-Silvestre (2015) first take the orthogonal projections with respect to deterministic components and thus estimate the common factors and factor loadings by employing principal components. Next, they recover the idiosyncratic error term through accumulation and test the unit root using ADF-type 
regression and the pseudo $t$-ratio $t_{\tilde{e}_{i}^{*}}^{\tau}$. Hence, the panel cointegration test statistics are constructed based on the sum of the individual ADF cointegration tests:

$$
S A D F_{\tau}(\lambda)=\sum_{i=1}^{N} t_{\tilde{e}_{i}^{*}}^{\tau}
$$

The limiting distribution of these statistics is given by:

$$
Z_{\tau}(\lambda)=\frac{N^{-1 / 2} S A D F_{\tau}(\lambda)-\Theta_{\tau}^{e}(\lambda) \sqrt{N}}{\sqrt{\Psi_{\tau}^{e}(\lambda)}} \Rightarrow N(0,1)
$$

where the detailed formula of $\Theta_{\tau}^{e}(\lambda)$ and $\Psi_{\tau}^{e}(\lambda)$ can be found in Theorem 2 of Banerjee and Carrion-i-Silvestre (2015). Note that we use Bai and Ng's (2004) BIC to obtain the optimum number of factors.

\subsection{Dynamic common correlated estimator}

To examine the influence of FDI on innovation, we employ the dynamic common correlated effects estimator proposed by Chudik and Pesaran (2015). The DCCE model has the advantages of controlling the dynamics of the dependent variable, dealing with potential endogeneity problems, and accounting for the cross-sectional dependence and heterogeneous slope coefficients through cross-sectional averages. ${ }^{1}$ The DCCE model that we use in this study is given as:

$$
\text { Innovation }_{i t}=c_{i}+\alpha \text { Innovation }_{i t-1}+\beta F D I_{i t}+\gamma^{\prime} X_{i t}+\xi_{i}{ }^{\prime} G_{t}+\mu_{i t},
$$

where Innovation $_{i t}$ represents the variable for innovation; FDI denotes foreign direct investment; $X_{i t}$ stands for some control variables, including economic development (Lngdpp), openness (Trade), population (Lnpop), urbanization (Urban), and estimated break points $(B P) ; c_{i}$ implies the country-specific effect; $G_{t}$ refers to the unobservable common factors, reflecting the global shocks; and $\mu_{i t}$ is the idiosyncratic errors that are serially correlated and weakly independent across countries.

To account for the common factor effect, we add the cross-sectional averages of the innovation variable and its lagged terms as well as the FDI variable to the dynamic panel model. Hence, the equation becomes:

$$
\text { Innovation }_{i t}=c_{i}+\alpha \text { Innovation }_{i t-1}+\beta F D I_{i t}+\gamma^{\prime} X_{i t}+\sum_{k=}^{P_{T}} \phi_{i k}^{\prime} \overline{z_{t-k}}+\mu_{i t},
$$

where $\overline{z_{t-k}}=\left(\overline{\text { Innovation }_{i t}}, \overline{\text { Innovation }_{i t-1}}, \overline{F D I_{i t}}, \overline{X_{i t}}\right)$ is the cross-sectional average of the dependent variable and the independent variable; and $P_{T}$ shows the lag number

1 The DCCE model provides more reliable and powerful results versus the pooled OLS model, the panel fixed-effects model, the panel random-effects model, and the general dynamic panel model. 
of cross-sectional average. Following Chudik and Pesaran (2015), the mean group estimates are given by:

$$
\widehat{\pi_{M G}}=\frac{1}{N} \sum_{i=1}^{N} \widehat{\pi_{i}},
$$

where $\widehat{\pi}_{i}=\left(\hat{\alpha}, \widehat{\beta}, \widehat{\gamma_{i}^{\prime}}\right)^{\prime}$ are obtained from the least square estimation for regression (23). The asymptotic distribution is hence developed as:

$$
\sqrt{N}\left(\widehat{\pi_{M G}}-E\left(\pi_{i}\right)\right) \Rightarrow N\left(0, \Sigma_{M G}\right)
$$

Note that $\Sigma_{M G}=\frac{1}{N-1} \sum_{i=1}^{N}\left(\widehat{\pi_{i}}-\widehat{\pi_{M G}}\right)\left(\widehat{\pi_{i}}-\widehat{\pi_{M G}}\right)^{\prime}$.

\section{Empirical Description}

\subsection{The data and variables}

This paper uses panel data for the period 1991-2016 in 34 countries. We gather Patent and Trademark from the World Intellectual Property Organization (WIPO). Additionally, the variable FDI is taken from the World Development Indicators (WDI) of the World Bank. Specifically, we employ the growth rate to the proxies Patent, Trademark, and $F D I{ }^{2}$ It is worth noting that $F D I$ is adjusted by purchasing power parity (PPP), which is the reason why the sample beginning year is 1991 as the converting factor to PPP appears in 1990, and the sample includes 34 countries as the panel unit root test needs balanced panel data.

In an effort to get evidence of the long-run influence of FDI on innovation, we plot the time series of the mean growth rate of Patent - FDI as well as Trademark - FDI in Figure 1. Figure 1a and Figure 1b correspond to Patent-FDI and Trademark - FDI, respectively. As can be seen in Figure 1a, there is an intuitive co-movement between the patent growth rate and the FDI growth rate. In particular, Patent and FDI show similar trends in the periods 1992-2002 and 2008-2016, indicating that there may exist a long-run co-movement relationship between the two. We also find that there is a break point in the co-movement of Patent and FDI. For instance, the patent growth rate shows a decreasing trend, while the FDI growth rate exhibits the opposite trend. Similarly, Figure $1 \mathrm{~b}$ shows the same trends for Trademark and FDI. Therefore, these trends in Figure 1 emphasize the importance of considering structural breaks in investigating the influence of FDI on innovation.

2 We are grateful to two referees for providing this advice. 
Figure 1: Plots of innovation and FDI (1991-2016)

(a) Patent-FDI

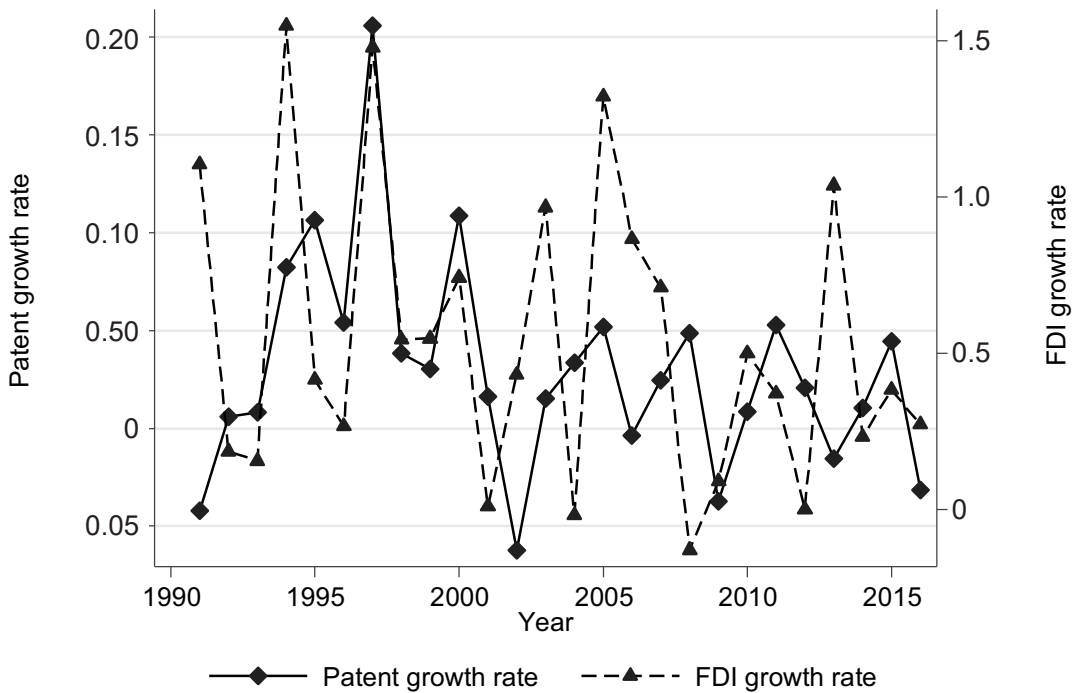

(b) Trademark-FDI

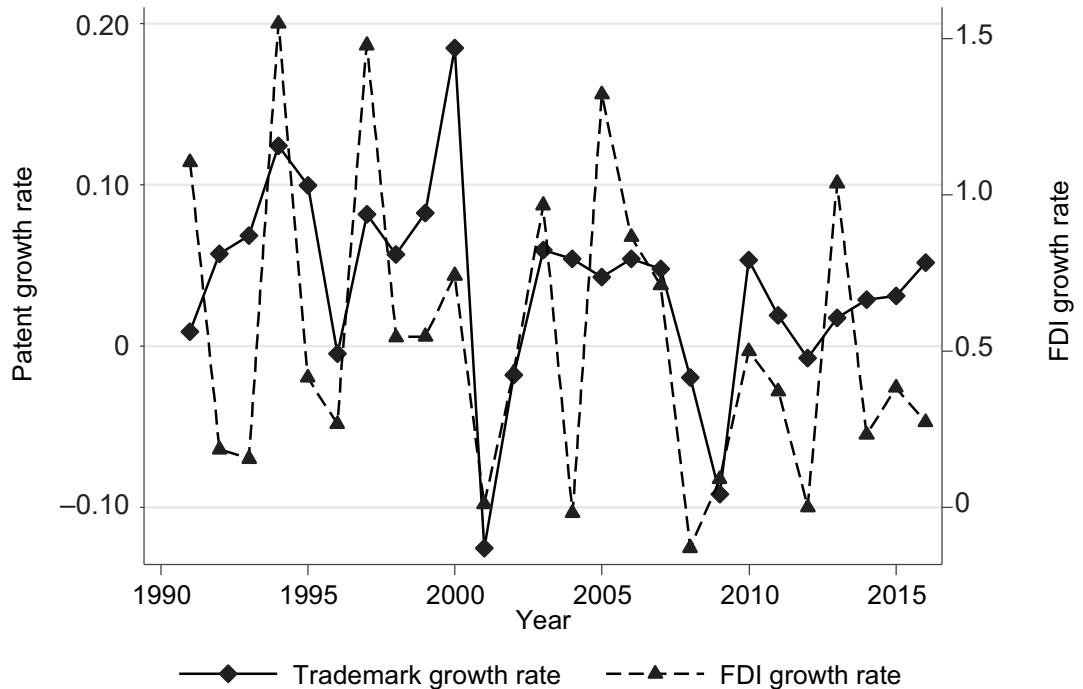

Source: Authors' calculations. 


\subsection{Empirical results}

\subsubsection{Results of panel unit root test with structural breaks}

Using the method proposed by Im et al. (2005), we estimate the individual-specific break point for each country and compute the panel statistics to verify the stationarity of the whole series. Table 1 presents the results of the panel LM unit test with structural breaks. As can be seen, the panel test statistics in all the models reject the null hypothesis of unit root with structural shifts, showing that the series of Patent, Trademark, and FDI are stationary when considering structural breaks. The individual LM unit root test statistics are significant in all the countries, suggesting that these variables in each country do not have unit roots under potential structural breaks. We also find that 22 out of 33 countries indicate a break point in 2001 for the variable $F D I$, showing a large fluctuation of FDI inflow in 2001. Overall, the results of our panel LM unit root test with structural breaks support the notion that it is necessary to account for structural breaks for examining the stationarity of innovation as well as FDI.

Even though the panel LM unit root test helps us understand the stationarity of innovation and FDI, it does not offer detailed information about the source of non-stationarity. The PANICCA test proposed by Reese and Westerlund (2016) is thus used to distinguish the source of non-stationarity from common shock and unit-specific shock. Table 2 reports the results of the PANICCA test where $\mathrm{P}=0$ denotes the model solely with intercept and $\mathrm{P}=1$ denotes the model with both intercept and trend. The results suggest that non-stationary shocks appear in Patent, Trademark, and FDI, which are mainly due to country-specific error/shocks since all the statistics for idiosyncratic component are not significant. Nevertheless, all the ADF statistics are significant at the conventional level, reflecting that the global trend only induces a temporary fluctuation in Patent, Trademark, and $F D I$ and that these trends will disappear in the long run. 
Table 1: Panel LM unit root test with one break

\begin{tabular}{|c|c|c|c|c|c|c|c|c|c|}
\hline \multirow[b]{2}{*}{ Country } & \multicolumn{3}{|c|}{ Patent } & \multicolumn{3}{|c|}{ Trademark } & \multicolumn{3}{|c|}{ FDI } \\
\hline & LM & $\mathbf{P}$ & BP & LM & $\mathbf{P}$ & BP & LM & $\mathbf{P}$ & BP \\
\hline Argentina & $-3.555^{*}$ & 7 & 2012 & $-4.918 *$ & 8 & 2004 & $-4.242 *$ & 3 & 2001 \\
\hline Austria & $-3.533 *$ & 8 & 2002 & $-4.533^{*}$ & 1 & 2002 & $-6.169 *$ & 0 & 2001 \\
\hline Bangladesh & $-4.219 *$ & 8 & 2009 & $-4.142 *$ & 8 & 2005 & $-4.026^{*}$ & 5 & 2012 \\
\hline Brazil & $-4.264 *$ & 8 & 2006 & $-3.757^{*}$ & 5 & 2013 & $-4.107 *$ & 8 & 2001 \\
\hline Bulgaria & $-3.978 *$ & 6 & 2009 & $-6.094 *$ & 8 & 2006 & $-5.468 *$ & 8 & 2001 \\
\hline Canada & $-3.900 *$ & 6 & 2007 & $-4.015 *$ & 8 & 2002 & $-5.348 *$ & 2 & 2001 \\
\hline Chile & $-3.216^{*}$ & 7 & 2008 & $-4.690 *$ & 6 & 2013 & $-5.303 *$ & 8 & 2007 \\
\hline Denmark & $-3.558 *$ & 0 & 2012 & $-4.994^{*}$ & 8 & 2004 & $-5.125^{*}$ & 3 & 2001 \\
\hline Finland & $-5.201 *$ & 5 & 2002 & $-7.032 *$ & 8 & 2011 & $-4.474 *$ & 0 & 2003 \\
\hline France & $-4.028 *$ & 1 & 2003 & $-3.843^{*}$ & 1 & 2013 & $-5.460 *$ & 8 & 2002 \\
\hline Germany & $-3.480 *$ & 1 & 2005 & $-3.632 *$ & 7 & 2001 & $-6.286 *$ & 7 & 2001 \\
\hline Iceland & $-3.988 *$ & 2 & 2008 & $-4.566^{*}$ & 1 & 2004 & $-5.448 *$ & 7 & 2001 \\
\hline India & $-3.873 *$ & 8 & 2008 & $-5.768 *$ & 7 & 2010 & $-5.015 *$ & 1 & 2001 \\
\hline Ireland & $-7.156 *$ & 7 & 2007 & $-5.196 *$ & 5 & 2010 & $-5.612 *$ & 6 & 2001 \\
\hline Israel & $-4.108 *$ & 7 & 2003 & $-5.385^{*}$ & 8 & 2003 & $-9.393 *$ & 8 & 2001 \\
\hline Italy & $-3.784^{*}$ & 2 & 2004 & $-4.025^{*}$ & 1 & 2006 & $-4.582 *$ & 8 & 2001 \\
\hline Japan & $-4.638 *$ & 8 & 2004 & $-4.033^{*}$ & 1 & 2005 & $-6.053 *$ & 7 & 2011 \\
\hline Korea, South & $-3.882 *$ & 1 & 2011 & $-5.091 *$ & 1 & 2001 & $-4.551 *$ & 5 & 2002 \\
\hline Malaysia & $-3.627 *$ & 0 & 2009 & $-2.803^{*}$ & 0 & 2009 & $-6.809 *$ & 6 & 2010 \\
\hline Mexico & $-6.092 *$ & 6 & 2013 & $-6.412 *$ & 6 & 2006 & $-4.893 *$ & 2 & 2013 \\
\hline New Zealand & $-7.001 *$ & 5 & 2012 & $-5.659 *$ & 8 & 2007 & $-4.347 *$ & 1 & 2001 \\
\hline Norway & $-4.037^{*}$ & 1 & 2010 & $-4.270 *$ & 7 & 2006 & $-5.272 *$ & 0 & 2001 \\
\hline Philippines & $-3.362 *$ & 7 & 2006 & $-6.984 *$ & 7 & 2002 & $-4.126 *$ & 7 & 2001 \\
\hline Poland & $-3.781 *$ & 0 & 2006 & $-3.915 *$ & 1 & 2003 & $-4.326 *$ & 3 & 2012 \\
\hline Portugal & $-5.956^{*}$ & 8 & 2011 & $-3.716 *$ & 0 & 2004 & $-3.863 *$ & 7 & 2003 \\
\hline Romania & $-4.926 *$ & 7 & 2002 & $-4.568 *$ & 8 & 2005 & $-5.819 *$ & 8 & 2001 \\
\hline South Africa & $-4.137^{*}$ & 2 & 2003 & $-3.682 *$ & 7 & 2001 & $-3.984 *$ & 8 & 2001 \\
\hline Spain & $-3.449 *$ & 5 & 2006 & $-4.880 *$ & 5 & 2007 & $-3.793 *$ & 0 & 2002 \\
\hline Sweden & $-3.431 *$ & 5 & 2010 & $-4.262 *$ & 7 & 2004 & $-3.772 *$ & 1 & 2013 \\
\hline Switzerland & $-3.812 *$ & 7 & 2005 & $-6.261 *$ & 8 & 2003 & $-9.057^{*}$ & 8 & 2001 \\
\hline Turkey & $-3.958 *$ & 5 & 2009 & $-6.266^{*}$ & 7 & 2010 & $-3.396 *$ & 0 & 2001 \\
\hline United Kingdom & $-3.393 *$ & 8 & 2001 & $-4.373^{*}$ & 5 & 2009 & $-7.789 *$ & 7 & 2001 \\
\hline United States & $-4.254 *$ & 8 & 2007 & $-3.412 *$ & 8 & 2004 & $-4.331 *$ & 5 & 2001 \\
\hline Vietnam & $-6.661 *$ & 8 & 2001 & $-5.998 *$ & 8 & 2002 & $-4.560 *$ & 0 & 2001 \\
\hline $\begin{array}{l}\text { Panel test } \\
\text { statistics }\end{array}$ & \multicolumn{3}{|c|}{$-43.403^{a}$} & \multicolumn{3}{|c|}{$-35.304^{a}$} & \multicolumn{3}{|c|}{$-11.182^{a}$} \\
\hline
\end{tabular}

Notes: P and BP denote optimal lags and estimated break point, respectively. ${ }^{*}$ corresponds to significance at the $5 \%$ level.

Source: Authors' calculations. 


\begin{tabular}{l|c|c|c|c|c|c|c|c}
\hline & \multicolumn{1}{|c|}{ Common Factors } & \multicolumn{5}{c}{ Idiosyncratic Component } \\
\hline Variable & $\mathbf{P = 0}$ & $\mathbf{P = 1}$ & \multicolumn{3}{|c|}{$\mathbf{P = 0}$} & \multicolumn{3}{c}{ P = 1 } \\
\hline & ADF & ADF & Pap & Pbp & PMSBp & Pap & Pbp & PMSBp \\
\hline Patent & -4.886 & -4.777 & 2.471 & 3.370 & 1.907 & 0.705 & 0.869 & 1.045 \\
\hline $\boldsymbol{p}$-value & 0.001 & 0.001 & 0.993 & 0.999 & 0.972 & 0.759 & 0.807 & 0.852 \\
\hline Trademark & -4.953 & -4.835 & 1.133 & 1.101 & 0.148 & -0.141 & -0.139 & -0.083 \\
\hline $\boldsymbol{p}$-value & 0.001 & 0.001 & 0.871 & 0.864 & 0.559 & 0.444 & 0.445 & 0.467 \\
\hline FDI & -5.070 & -5.086 & -0.174 & -0.198 & 0.470 & 0.361 & 0.409 & 0.492 \\
\hline $\boldsymbol{p}$-value & 0.001 & 0.001 & 0.431 & 0.422 & 0.681 & 0.641 & 0.659 & 0.689 \\
\hline
\end{tabular}

Source: Authors' calculations.

\subsubsection{Results of panel cointegration test with structural breaks}

As we have confirmed that Patent, Trademark, and FDI show stationarity with structural break, we next examine whether there exists a long-run cointegrated relationship between innovation and FDI. The results of the panel cointegration test with structural shifts developed by Westerlund and Egerton (2008) are presented in Table 3. The cointegration results in Panel B of Table 3 indicate that the null of no integration could be rejected at the $1 \%$ level in the regime-shift model with breaks in both intercept and slope. In fact, the results in the no-shift model also show a co-movement for Patent-FDI and Trademark-FDI. However, the statistics in the no-shift model are less powerful as they turn out to be insignificant after accounting for the shift in the intercept in the model. Based on these results, we confirm a cointegration relationship with structural breaks between innovation and FDI. Accordingly, the results further indicate that it is necessary to consider multiple structural breaks in the estimation of the panel long-run cointegration test.

The results of Panel A in Table 3 also exhibit the locations of structural breaks. It is worth noting that the year 2000 shows a structural break in most countries for the Trademark-FDI model. This reflects a fluctuation in the cointegrated relationship between Trademark and FDI. A possible explanation is that transnational terrorism, such as the terrorist attacks of 11 September 2001, has led to huge fluctuations in FDI. As Powers and Choi (2012) argue, business-related terrorism can reduce FDI flows by damaging buildings, destroying products, killing workers, and raising insurance expenditures (Enders et al., 2006). 
Table 3: Panel cointegration test of Westerlund and Edgerton (2008)

\begin{tabular}{l|c|c|l|c|c}
\hline \multicolumn{5}{c}{ Panel A: Estimated break point } \\
\hline Country & $\begin{array}{c}\text { Patent- } \\
\text { FDI }\end{array}$ & $\begin{array}{c}\text { Trademark- } \\
\text { FDI }\end{array}$ & Country & $\begin{array}{c}\text { Patent- } \\
\text { FDI }\end{array}$ & $\begin{array}{c}\text { Trademark- } \\
\text { FDI }\end{array}$ \\
\hline Argentina & 1993 & 2003 & Korea & 1997 & 2000 \\
\hline Austria & 1995 & 1995 & Malaysia & 1999 & 2000 \\
\hline Bangladesh & 1996 & 2006 & Mexico & 1994 & 1993 \\
\hline Brazil & 1993 & 2006 & New Zealand & 1995 & 1998 \\
\hline Bulgaria & 1997 & 2000 & Norway & 1995 & 2000 \\
\hline Canada & 1999 & 2000 & Philippines & 2007 & 1997 \\
\hline Chile & 2012 & 1995 & Poland & 2010 & 2000 \\
\hline Denmark & 2010 & 2000 & Portugal & 1998 & 2000 \\
\hline Finland & 2000 & 2000 & Romania & 2002 & 1997 \\
\hline Grance & 1993 & 2000 & South Africa & 1996 & 2000 \\
\hline Isermany & 2008 & 1996 & Spain & 2009 & 1998 \\
\hline India & 1996 & 1995 & Sweden & 2002 & 1993 \\
\hline
\end{tabular}

Japan

Panel B: Cointegration test with shift

\begin{tabular}{l|c|c|c|c}
\hline & \multicolumn{2}{|c|}{ Patent-FDI } & \multicolumn{2}{c}{ Trademark-FDI } \\
\hline No shift & $\boldsymbol{Z}_{\boldsymbol{\tau}}$ & $\boldsymbol{Z}_{\boldsymbol{\varphi}}$ & $\boldsymbol{Z}_{\boldsymbol{\tau}}$ & $\boldsymbol{Z}_{\boldsymbol{\varphi}}$ \\
\hline $\boldsymbol{p}$-value & -9.426 & -11.987 & -7.330 & -11.201 \\
\hline Level shift & 0.000 & 0.000 & 0.000 & 0.000 \\
\hline $\boldsymbol{p}$-value & -0.169 & 0.376 & 0.548 & 0.275 \\
\hline Regime shift & 0.433 & 0.647 & 0.708 & 0.608 \\
\hline $\boldsymbol{p}$-value & -2.604 & -2.259 & -9.861 & -14.173 \\
\hline
\end{tabular}

\section{Panel C: DOLS estimation}

\begin{tabular}{l|l|c}
\hline Dependent variables & Independent variables & Panel \\
\hline Patent & FDI & $0.004(1.979)^{*}$ \\
\hline FDI & Patent & $-23.500(0.432)$ \\
\hline Trademark & FDI & $0.001(-2.352) *$ \\
\hline FDI & Trademark & $-143.400(-1.944) * *$ \\
\hline
\end{tabular}

Notes: $Z_{\tau}$ and $Z \varphi$ represent two different statistics of panel cointegration with structural break in Westerlund and Edgerton (2008). No shift implies no break. Level shift implies one break in the intercept. Regime shift implies break in both intercept and slope. ${ }^{*}$ and ${ }^{* *}$ indicate statistical significance at the $5 \%$ and $10 \%$ levels. The t-statistics are in parentheses in Panel C.

Source: Authors' calculations. 
Table 4: Panel cointegration test of Banerjee and Carrion-i-Silvestre (2015)

Panel A: Break points

\begin{tabular}{l|c|c|l|c|c}
\hline Country & $\begin{array}{c}\text { Patent- } \\
\text { FDI }\end{array}$ & $\begin{array}{c}\text { Trademark- } \\
\text { FDI }\end{array}$ & Country & $\begin{array}{c}\text { Patent- } \\
\text { FDI }\end{array}$ & $\begin{array}{c}\text { Trademark- } \\
\text { FDI }\end{array}$ \\
\hline Argentina & 2000 & 2002 & Korea & 1997 & 2001 \\
\hline Austria & 1994 & 1994 & Malaysia & 1999 & 2000 \\
\hline Bangladesh & 1996 & 2006 & Mexico & 2008 & 1996 \\
\hline Brazil & 2003 & 2006 & New Zealand & 1997 & 1998 \\
\hline Bulgaria & 1996 & 2010 & Norway & 1994 & 2009 \\
\hline Canada & 1998 & 2001 & Philippines & 2007 & 1997 \\
\hline Chile & 2011 & 2002 & Poland & 2009 & 2001 \\
\hline Denmark & 2008 & 2010 & Portugal & 1997 & 2003 \\
\hline Finland & 2008 & 2001 & Romania & 2001 & 2009 \\
\hline France & 2005 & 1998 & South Africa & 2005 & 2003 \\
\hline Germany & 2007 & 2001 & Spain & 1993 & 1999 \\
\hline Iceland & 1995 & 2008 & Sweden & 1998 & 2006 \\
\hline India & 2009 & 2000 & Switzerland & 2000 & 2000 \\
\hline Ireland & 1998 & 1993 & Turkey & 2001 & 2010 \\
\hline Israel & 2006 & 2009 & United Kingdom & 1995 & 2000 \\
\hline Italy & 2000 & 1996 & United States & 2009 & 1996 \\
\hline Japan & 2003 & 2000 & Vietnam & 1998 & 2007 \\
\hline
\end{tabular}

Panel B: Panel test statistics

\begin{tabular}{l|c|c}
\hline & Patent-FDI & Trademark-FDI \\
\hline $\begin{array}{l}\text { \% Individual rejections } \\
\text { at the 5\% significance level }\end{array}$ & $61.8 \%$ & $82.3 \%$ \\
\hline Panel test statistic & $-5.9 \mathrm{E}+15$ & $-1.6 \mathrm{E}+16$ \\
\hline $\boldsymbol{p}$-value & 0.001 & 0.001 \\
\hline$\hat{\boldsymbol{r}}$ & 12 & 12 \\
\hline$\hat{\boldsymbol{r}} \boldsymbol{P}$ & 12 & 12 \\
\hline$\hat{\boldsymbol{r}} \boldsymbol{N P}$ & 12 & 12 \\
\hline
\end{tabular}

Panel C: DOLS estimation

\begin{tabular}{l|l|c}
\hline Dependent variables & Independent variables & Panel \\
\hline Patent & FDI & $0.003(2.253)^{*}$ \\
\hline FDI & Patent & $25.680(1.545)$ \\
\hline Trademark & FDI & $0.005(0.041)$ \\
\hline FDI & Trademark & $7.538(-0.027)$ \\
\hline
\end{tabular}

Notes: The break point in Panel A is estimated using Model 5 in Banerjee and Carrion-i-Silvestre (2015). $\hat{r}$ refers to the number of common factors. $\hat{r} P$ and $\hat{r} N P$ represent the number of common stochastic trends (Parametric) and number of common stochastic trends (Non-parametric). " and ${ }^{* *}$ indicate statistical significance at the $5 \%$ and $10 \%$ levels. The $t$-statistics are in parentheses in Panel C.

Source: Authors' calculations. 
Overall, with Westerlund (2006) and Chang et al. (2011) having confirmed structural breaks in GDP, our results suggest the necessity of considering structural changes when studying the association between FDI and innovation. Once we establish that FDI and innovation are related, we next estimate the long-run relationship using the dynamic ordinary least squares (DOLS) model; the corresponding results are presented in Panel C of Table 3. ${ }^{3}$ Overall, our evidence indicates that when the dependent variable is Patent (Trademark), the panel estimation has a significantly positive sign, showing that FDI presents a long-run positive influence on innovation.

To ensure the robustness of the cointegration relationship, we further utilize the panel cointegration test proposed by Banerjee and Carrion-i-Silvestre (2015). The results of the panel cointegration test of Banerjee and Carrion-i-Silvestre (2015) are provided in Table $4 .{ }^{4}$ Similarly, Panels A, B and C correspond to these break points, panel statistics and DOLS estimation. As can be seen in Panel B of Table 4, the percentage of rejecting the spurious regression ranges from $61.8 \%$ to $81.3 \%$. Moreover, the panel test statistics constructed based on individual information also reject the null hypothesis of no integration at the $1 \%$ level of significance no matter which model is used. The results of Panel C with DOLS in Table 4 suggest that FDI exhibits a long-run positive influence on innovation when the dependent variable is Patent while this effect becomes insignificant when the dependent variable is Trademark. These results lend strong support to the argument that there is a long-run cointegrated relationship between innovation and FDI after taking structural breaks into consideration.

\subsubsection{DCCE estimation}

Though the long-run positive cointegrated relationship is established, the causal relationship between FDI and innovation is still unclear. We further employ the dynamic common correlated estimator proposed by Chudik and Pesaran (2015), which can deal with the endogenous problem and cross-sectional dependence, to examine the causal effect of FDI on innovation. ${ }^{5}$ In the estimation, we include the control variables separately, the break point variable, the economic development and population variable, and all of the control variables. It should be noted that the control variables include economic development (Lngdpp), openness (Trade), population (Lnpop), urbanization (Urban), and corruption level (Corruption).

3 The DOLS model is not simply fully parametric, but also combines with the leads and lags of the independent variables, offering reliable evidences for the long-run relationship. The estimated break points are included in the DOLS model.

4 To maintain consistency with Westerlund and Egerton (2008), we consider one break in the panel cointegration test.

5 We are grateful to referees for providing this advice. 


\begin{tabular}{|c|c|c|c|c|c|c|}
\hline & (1) & (2) & (3) & (4) & (5) & (6) \\
\hline & Patent & Patent & Patent & Trademark & Trademark & Trademark \\
\hline L.Patent & $\begin{array}{c}0.023 \\
(0.479)\end{array}$ & $\begin{array}{l}-0.191^{*} \\
(-2.181)\end{array}$ & $\begin{array}{l}-0.417^{*} \\
(-4.755)\end{array}$ & - & - & - \\
\hline L.Trademark & - & - & - & $\begin{array}{c}0.040 \\
(0.824)\end{array}$ & $\begin{array}{l}-0.071^{*} \\
(-2.704)\end{array}$ & $\begin{array}{l}-0.221^{*} \\
(-2.989)\end{array}$ \\
\hline FDI & $\begin{array}{l}0.013^{* *} \\
(1.932)\end{array}$ & $\begin{array}{c}0.013 \\
(0.989)\end{array}$ & $\begin{array}{l}0.031^{* *} \\
(1.704)\end{array}$ & $\begin{array}{c}0.007 \\
(0.788)\end{array}$ & $\begin{array}{l}0.010^{*} \\
(2.230)\end{array}$ & $\begin{array}{l}0.021^{*} \\
(2.092)\end{array}$ \\
\hline Lngdpp & - & $\begin{array}{l}0.210^{*} \\
(4.226)\end{array}$ & $\begin{array}{l}1.321^{*} \\
(2.589)\end{array}$ & - & $\begin{array}{c}-0.125 \\
(-0.645)\end{array}$ & $\begin{array}{l}0.229^{*} \\
(2.783)\end{array}$ \\
\hline Lnpop & - & $\begin{array}{c}0.199 \\
(0.105)\end{array}$ & $\begin{array}{c}-7.170 \\
(-1.202)\end{array}$ & - & $\begin{array}{c}0.604 \\
(0.656)\end{array}$ & $\begin{array}{c}0.746 \\
(0.300)\end{array}$ \\
\hline Urban & - & - & $\begin{array}{l}25.129 \\
(0.798)\end{array}$ & - & - & $\begin{array}{l}-19.854 \\
(-1.410)\end{array}$ \\
\hline Trade & - & - & $\begin{array}{l}0.894^{*} \\
(2.001)\end{array}$ & - & - & $\begin{array}{l}0.130^{*} \\
(4.649)\end{array}$ \\
\hline Corruption & - & - & $\begin{array}{c}0.119 \\
(1.244)\end{array}$ & - & - & $\begin{array}{c}-0.013 \\
(-0.421)\end{array}$ \\
\hline BP1 & $\begin{array}{c}0.020 \\
(0.304)\end{array}$ & $\begin{array}{c}0.004 \\
(0.046)\end{array}$ & $\begin{array}{l}0.041^{*} \\
(1.999)\end{array}$ & - & - & - \\
\hline BP2 & - & - & - & $\begin{array}{c}-0.005 \\
(-0.203)\end{array}$ & $\begin{array}{l}0.006 \\
(0.178)\end{array}$ & $\begin{array}{c}-0.001 \\
(-0.026)\end{array}$ \\
\hline$N$ & 748 & 748 & 748 & 748 & 748 & 748 \\
\hline$R^{2}$ & 0.380 & 0.546 & 0.803 & 0.327 & 0.517 & 0.806 \\
\hline CD (p-value) & 0.389 & 0.201 & 0.177 & 0.060 & 0.137 & 0.539 \\
\hline
\end{tabular}

Notes: The $z$-statistics are in parentheses. The regression includes a constant term. CDP implies the corresponding $p$-value. " and " indicate statistical significance at the 5\% and 10\% levels. BP1 and BP2 imply the break point variable estimated from the panel cointegration test of Banerjee and Carrion-i-Silvestre (2015).

Source: Authors' calculations.

Table 5 presents the results of the DCCE models. We incorporate the structural break estimated in Banerjee and Carrion-i-Silvestre (2015) as a variable into the regression. The Pesaran (2015) cross-sectional dependence (CD) test results are reported at the bottom 
of Table 5. We see that all the models pass the CD test, and thereby these models cannot reject the null hypothesis of no cross-sectional dependence. Thus, the validity of the models is verified by the CD test. Moreover, the variable FDI is positive and statistically significant at least at the $10 \%$ level in all the models except columns 2 and 4 in Table 5, implying that FDI has a long-run positive influence on innovation regardless whether the measure of innovation is Patent or Trademark. This finding is in line with Vahter (2011), who shows that FDI can promote domestic innovation.

Table 6: DCCE model estimation: subsample results

\begin{tabular}{l|c|c|c|c}
\hline Subsample & EU & EU & Non-EU & Non-EU \\
\hline Variables & Patent & Trademark & Patent & Trademark \\
\hline L. Patent & $\begin{array}{c}-0.210^{* *} \\
(-1.983)\end{array}$ & - & $\begin{array}{c}-0.190^{*} \\
(-2.643)\end{array}$ & - \\
\hline L. Trademark & - & $-0.212^{*}$ & - & $-0.281^{*}$ \\
\hline FDI & $0.008^{* *}$ & $0.013^{* *}$ & $0.019^{*}$ & $0.005^{*}$ \\
\hline Lngdpp & $(1.910)$ & $(1.756)$ & $(2.580)$ & $(2.108)$ \\
\hline Lnpop & -0.171 & 0.794 & $2.482^{*}$ & $1.190^{*}$ \\
\hline Urban & $(-0.282)$ & $(1.232)$ & $(2.411)$ & $(2.391)$ \\
\hline Trade & 1.209 & $-3.835^{* *}$ & $-12.374^{* *}$ & 1.296 \\
\hline Corruption & $(0.388)$ & $(-1.836)$ & $(-1.864)$ & $(0.374)$ \\
\hline $\boldsymbol{N}$ & 10.801 & 4.559 & 73.367 & -14.060 \\
\hline $\boldsymbol{R}^{2}$ & $(0.657)$ & $(0.580)$ & $(0.771)$ & $(-0.459)$ \\
\hline CD (p-value) & $-0.296^{*}$ & 0.468 & -0.121 & 0.381 \\
\hline & $(-2.905)$ & $(1.622)$ & $(-0.292)$ & $(1.181)$ \\
\hline & 0.049 & 0.047 & -0.058 & 0.004 \\
$(196)$ & $(1.384)$ & $(-0.831)$ & $(0.161)$ \\
\hline & 0.492 & 0.565 & 0.554 & 0.564 \\
\hline & 0.808 & 0.552 & 0.506 \\
\hline
\end{tabular}

Notes: EU represents European countries, including Austria, Bulgaria, Denmark, Finland, France, Germany, Iceland, Ireland, Italy, Norway, Poland, Portugal, Romania, Spain, Sweden, Switzerland, Turkey, and the United Kingdom. Symbols are the same as in Table 5.

Source: Authors' calculations. 
As a robustness check, we divide our sample into an EU group (countries that are in Europe) and a Non-EU group and re-estimate the long-run influence of FDI on innovation using the DCCE models. The results for the subsamples are presented in Table 6. The variable FDI is positive and statistically significant at the $10 \%$ level in all the models, reflecting that FDI contributes to national innovation in both European countries and non-European countries. Therefore, the results of the subsamples exhibit strong evidence of the notion in the full sample that FDI has a positive influence on technological innovation in the long run.

\section{Conclusions}

Employing data from a panel of 34 countries for the period 1991-2016, this paper examines the influence of FDI on innovation by taking structural breaks into consideration in the panel stationarity test and the panel cointegration test. More importantly, we use the dynamic common correlated estimator to examine the long-run impact of FDI on innovation. Our results indicate that FDI, Patent, and Trademark follow a stationary trend under the panel LM unit root test with structural breaks. The results of the panel cointegration test reveal a long-run cointegration relationship between FDI and Patent as well as between FDI and Trademark when structural breaks are considered. The DCCE estimation hence indicates that FDI has a long-run positive influence on innovation both in the full sample and in two subsamples. We believe that our findings shed crucial insights into the long-run relationship between FDI and innovation and provide new evidence for research into FDI and innovation when considering potential structural changes.

\section{References}

Aitken, B. J., Harrison, A. E. (1999). Do Domestic Firms Benefit From Direct Foreign Investment? Evidence from Venezuela. American Economic Review, 89(3), 605-618, https://doi.org/10.1257/aer.89.3.605

Amsler, C., Lee, J. (1995). An LM Test for a Unit Root in The Presence of a Structural Change. Econometric Theory, 11(2), 359-368, https://doi.org/10.1017/S026646660000921X

Bai, J., Ng, S. (2004). A PANIC Attack on Unit Roots and Cointegration. Econometrica, 72(4), 1127-1177, https://doi.org/10.1111/j.1468-0262.2004.00528.x

Banerjee, A., Carrion-i-Silvestre, J. L. (2015). Cointegration in Panel Data with Structural Breaks and Cross-Section Dependence. Journal of Applied Econometrics, 30(1), 1-23, https://doi. org/10.1002/jae.2348

Chang, C.-P., Lee, C.-C. (2015). Do Oil Spot and Futures Prices Move Together? Energy Economics, 50, 379-390, https://doi.org/10.1016/j.eneco.2015.02.014 
Chang, C.-P., Lee, C.-C., Hsieh, M.-C. (2011). Globalization, Real Output and Multiple Structural Breaks. Global Economic Review, 40(4), 421-444, https://doi.org/10.1080/12265 08X.2011.626154

Chen, C.-I., Yeh, C.-H. (2012). Re-Examining Location Antecedents and Pace of Foreign Direct Investment: Evidence from Taiwanese Investments in China. Journal of Business Research, 65(8), 1171-1178, https://doi.org/10.1016/j.jbusres.2011.07.032

Cheung, K.-y., Lin, P. (2004). Spillover Effects of FDI on Innovation in China: Evidence from the Provincial Data. China Economic Review, 15(1), 25-44, https://doi.org/10.1016/ s1043-951x(03)00027-0

Chudik, A., Pesaran, M. H. (2015). Common Correlated Effects Estimation of Heterogeneous Dynamic Panel Data Models with Weakly Exogenous Regressors. Journal of Econometrics, 188(2), 393-420, https://doi.org/10.1016/j.jeconom.2015.03.007

Cui, L., Meyer, K. E., Hu, H. W. (2014). What Drives Firms' Intent to Seek Strategic Assets by Foreign Direct Investment? A Study of Emerging Economy Firms. Journal of World Business, 49(4), 488-501, https://doi.org/10.1016/j.jwb.2013.12.003

Dunning, J. H. (2000). The Eclectic Paradigm as an Envelope for Economic and Business Theories of MNE Activity. International Business Review, 9(2), 163-190, https://doi.org/10.1016/S0969-5931(99)00035-9

Enders, W., Sachsida, A., Sandler, T. (2006). The Impact of Transnational Terrorism on US Foreign Direct Investment. Political Research Quarterly, 59(4), 517-531, https://doi.org/10.1177/106591290605900402

Girma, S., Gong, Y., Görg, H., Lancheros, S. (2015). Estimating Direct and Indirect Effects of Foreign Direct Investment on Firm Productivity In The Presence Of Interactions between Firms. Journal of International Economics, 95(1), 157-169, https://doi.org/10.1016/j.jinteco.2014.11.007

Haskel, J. E., Pereira, S. C., Slaughter, M. J. (2007). Does Inward Foreign Direct Investment Boost The Productivity Of Domestic Firms? The Review of Economics and Statistics, 89(3), 482-496, https://doi.org/10.1162/rest.89.3.482

Im, K. S., Lee, J., Tieslau, M. (2005). Panel LM Unit-Root Tests with Level Shifts. Oxford Bulletin of Economics and Statistics, 67(3), 393-419, https://doi. org/10.1111/j.1468-0084.2005.00125.x

Javorcik, B. S., Spatareanu, M. (2011). Does It Matter Where You Come From? Vertical Spillovers from Foreign Direct Investment and the Origin of Investors. Journal of Development Economics, 96(1), 126-138, https://doi.org/10.1016/j.jdeveco.2010.05.008

Jeon, Y., Park, B. I., Ghauri, P. N. (2013). Foreign Direct Investment Spillover Effects in China: Are They Different Across Industries with Different Technological Levels?. China Economic Review, 26, 105-117, https://doi.org/10.1016/j.chieco.2013.05.001

Kim, J. U., Aguilera, R. V. (2016). Foreign Location Choice: Review and Extensions. International Journal of Management Reviews, 18(2), 133-159, https://doi.org/10.1111/ijmr.12064 
Li, J., Sutherland, D., Ning, L. (2017). Inward FDI Spillovers and Innovation Capabilities in Chinese Business: Exploring the Moderating Role of Local Industrial Externalities. Technology Analysis \& Strategic Management, 29(8), 932-945, https://doi.org/10.1080/09 537325.2016 .1259472

Liang, F. H. (2017). Does Foreign Direct Investment Improve The Productivity Of Domestic Firms? Technology Spillovers, Industry Linkages, and Firm Capabilities. Research Policy, 46(1), 138-159, https://doi.org/10.1016/j.respol.2016.08.007

Lu, Y., Tao, Z., Zhu, L. (2017). Identifying FDI Spillovers. Journal of International Economics, 107, 75-90, https://doi.org/10.1016/j.jinteco.2017.01.006

Madsen, J. B., Islam, M. R., Ang, J. B. (2010). Catching Up to The Technology Frontier: The Dichotomy between Innovation and Imitation. Canadian Journal of Economics, 43(4), 1389-1411, https://doi.org/10.1111/j.1540-5982.2010.01618.x

Malik, S. K. (2015). Conditional Technology Spillovers from Foreign Direct Investment: Evidence from Indian Manufacturing Industries. Journal of Productivity Analysis, 43(2), 183-198, https://doi.org/10.1007/s11123-014-0425-8

Nielsen, B. B., Asmussen, C. G., Weatherall, C. D. (2017). The Location Choice of Foreign Direct Investments: Empirical Evidence and Methodological Challenges. Journal of World Business, 52(1), 62-82, https://doi.org/10.1016/j.jwb.2016.10.006

Pesaran, M. H. (2015). Testing Weak Cross-Sectional Dependence in Large Panels. Econometric Reviews, 34(6-10), 1089-1117, https://doi.org/10.1080/07474938.2014.956623

Powers, M., Choi, S.-W. (2012). Does Transnational Terrorism Reduce Foreign Direct Investment? Business-Related Versus Non-Business-Related Terrorism. Journal of Peace Research, 49(3), 407-422, https://doi.org/10.1177/0022343312436768

Ramasamy, B., Yeung, M., Laforet, S. (2012). China's Outward Foreign Direct Investment: Location Choice and Firm Ownership. Journal of World Business, 47(1), 17-25, https://doi.org/10.1016/j.jwb.2010.10.016

Reese, S., Westerlund, J. (2016). PANICCA: Panic on Cross-Section Averages. Journal of Applied Econometrics, 31(6), 961-981, https://doi.org/10.1002/jae.2487

Santangelo, G. D., Meyer, K. E. (2011). Extending the Internationalization Process Model: Increases and Decreases of MNE Commitment in Emerging Economies. Journal of International Business Studies, 42(7), 894-909, https://doi.org/10.1057/jibs.2011.25

Sbia, R., Shahbaz, M., Hamdi, H. (2014). A Contribution of Foreign Direct Investment, Clean Energy, Trade Openness, Carbon Emissions and Economic Growth to Energy Demand in UAE. Economic Modelling, 36, 191-197, https://doi.org/10.1016/j. econmod.2013.09.047

Seker, F., Ertugrul, H. M., Cetin, M. (2015). The Impact of Foreign Direct Investment on Environmental Quality: A Bounds Testing and Causality Analysis for Turkey. Renewable and Sustainable Energy Reviews, 52, 347-356, https://doi.org/10.1016/j. rser.2015.07.118 
Solarin, S. A., Shahbaz, M. (2015). Natural Gas Consumption and Economic Growth: The Role of Foreign Direct Investment, Capital Formation and Trade Openness in Malaysia. Renewable and Sustainable Energy Reviews, 42, 835-845, https://doi.org/10.1016/j. rser.2014.10.075

Stiebale, J., Reize, F. (2011). The Impact of FDI through Mergers and Acquisitions on Innovation in Target Firms. International Journal of Industrial Organization, 29(2), 155-167, https://doi.org/10.1016/j.ijindorg.2010.06.003

Vahter, P. (2011). Does FDI Spur Productivity, Knowledge Sourcing and Innovation by Incumbent Firms? Evidence from Manufacturing Industry in Estonia. The World Economy, 34(8), 1308-1326, https://doi.org/10.1111/j.1467-9701.2011.01379.x

Westerlund, J. (2006). Testing for Panel Cointegration with Multiple Structural Breaks. Oxford Bulletin of Economics and Statistics, 68(1), 101-132, https://doi. org/10.1111/j.1468-0084.2006.00154.x

Westerlund, J., Edgerton, D. L. (2008). A Simple Test for Cointegration in Dependent Panels with Structural Breaks. Oxford Bulletin of Economics and Statistics, 70(5), 665-704, https://doi.org/10.1111/j.1468-0084.2008.00513.x 